\title{
Long-Term Variability of Asian Summer Monsoon Rainfall during 1946-1988
}

\author{
By Masahiro Watanabe ${ }^{1}$ and Masato Shinoda \\ Department of Geography, Tokyo Metropolitan University, 1-1 Minami-Osawa, Hachioji-shi, Tokyo 192-03, Japan
}

(Manuscript received 29 January 1996, in revised form 18 October 1996)

\begin{abstract}
An observational study has been made of the long-term variability of Asian summer monsoon rainfall for the period 1946-1988 and its relationship to global sea-surface temperatures (SSTs) and geopotential height fields.

The trend analysis of June-September rainfall for the recent four decades shows a distinct long-term trend in rainfall over several Asian regions; increasing trends in southwest India, and decreasing trends in northwest and central India, on the south side of the Himalayas, and in the western Indochina peninsula facing the Bay of Bengal.

A rotated empirical orthogonal function (R-EOF) analysis was applied to global SSTs for the above 43-year period (Shinoda and Kawamura, 1994). The second R-EOF (R-EOF2) mode exhibits the warming trend of the Indian Ocean. The correlation analysis between the time coefficients of the R-EOF2 mode and monsoon rainfall shows that the trend components which are observed in both the R-EOF2 mode and rainfall for the above areas are responsible for the high correlation between them.

The R-EOF2 mode is highly correlated not only with monsoon rainfall, but also with tropical $850 \mathrm{hPa}$ geopotential heights. This correlation pattern exhibits an east-west contrast having positive correlations over Africa and the western Pacific Ocean and negative correlations over the northern Indian Ocean. The above positive and negative correlations coincide with the increasing and decreasing trends in $850 \mathrm{hPa}$ heights.

Over the Indian subcontinent, areas having negative and positive trends of $850 \mathrm{hPa}$ heights coincide with those having increasing and decreasing trends in régional rainfall, respectively. On a monthly basis, for June and August, the Indian subcontinent is extensively covered with areas having increasing trends in rainfall and decreasing trends in $850 \mathrm{hPa}$ heights, whereas the areas are limited to southwest India during Júly and September.
\end{abstract}

\section{Introduction}

Recently, much attention has been paid to the long-term climate change over the century in relation to global warming. As for the tropics and subtropics, precipitation has decreased, especially since the mid-century, over large regions extending from northern Africa to southeast Asia and Indonesia (IPCC, 1996).

Numerous attempts have so far been made to investigate the long-term variability of all-India rainfall. Mooley and Parthasarathy (1984) pointed out significant 14 and 2.8 year periodicities in all-India rainfall through spectral analysis, while Parthasarathy et al. (1991; 1994) suggested a transition between two climatic régimes with a period longer than 30 years. The two regimes are related to the "meridional monsoon" and "zonal monsoon"

1 Present affiliation: Center for Climate System Research, University of Tokyo

(C)1996, Meteorological Society of Japan circulation (Fu and Fletcher, 1988). These studies, however, agree on the point that the long-term trend is hardly found over a long period of nearly one century. On an interannual time scale, Ropelewski and Halpert (1987) showed that summer rainfall uniformly fluctuates over most of India, being closely related to the El Niño/Southern Oscillation (ENSO). Therefore, all-India rainfall is a useful index for examining ENSO-related monsoon variability.

On the other hand, it should be noted that an obvious trend in Asian monsoon rainfall is observed over several regions (Jagannathan and Parthasarathy, 1973; Alvi and Koteswaram, 1985). For example, increasing trends in summer rainfall were found along the Indian west coast during 18711984, while decreasing trends exist over the areas adjoining northeast India (Kumar et al., 1992). The summer rainfall averaged over Indian administrative subdivisions, which is often used, does not represent the reality of the regional rainfall variability (Kumar 
et al., 1992). Thus, this study is aimed to investigate, on the basis of station rainfall data, the regional difference in the long-term variability of Asian monsoon rainfall. The focus of this investigation is placed not only on India but also on the Indochina peninsula, since the summer monsoon over these two regions is regarded as one unit in the global monsoon system, judging from rainfall and OLR distributions (Murakami and Matsumoto, 1994; Kripalani and Singh, 1993).

It is well known that sea-surface temperatures (SSTs) over the Arabian Sea have a significant negative correlation with the monsoon westerlies related to Indian summer rainfall due to air-sea interaction (Shukla and Misra, 1977; Ghosh et al., 1978; Raghavan et al., 1978; Weare, 1979; Cadet and Diehl, 1984; Rao and Goswami, 1988). That is, the strong westerlies over the Arabian Sea lead to the upwelling of the sea-surface layer, namely, negative SST anomalies and sufficient Indian rainfall (Shukla, 1987). On the other hand, the Indian Ocean reveals a dominant warming trend during recent decades (Nitta and Yamada, 1989; Kawamura, 1994). Shinoda and Kawamura (1994) and Shinoda (1995) concluded that the recent reduction in Sahelian rainfall is closely related to the warming trends of the Indian Ocean.

Motivated by the question as to how the warming trends of the Indian Ocean affect Asian summer monsoon rainfall, the present study explores through correlation and trend analyses the relationships between global SSTs, especially their trend components, Asian monsoon rainfall, and the tropical east-west circulation. The period of analysis is confined to 43 years from 1946 to 1988 because the warming trends of the Indian Ocean have been observed since the 1950 s.

\section{Data}

The data used in this study consist of Asian rainfall, global upper-air, and global sea-surface temperature observations on monthly and seasonal (JuneSeptember) base.

The monthly precipitation data are obtained from the Global Historical Climatology Network (GHCN), compiled by the Carbon Dioxide Information Analysis Center (CDIAC), and available only before 1990. The data observed at each of 375 raingauge stations in the extensive area of $60^{\circ} \mathrm{E}-110^{\circ} \mathrm{E}$, the equator $-40^{\circ} \mathrm{N}$ for the period 1946-1988 are analyzed because the data after 1989 have less observations.

The upper-air observation data are obtained from the Monthly Climatic Data for the World, compiled by the National Oceanic and Atmospheric Administration (NOAA). Although these data are available from the early 1950 's to 1987 , only the data after 1957 are used because the ascent times of rawin- sonde were changed in April 1957 (Parker and Cox, 1995).

The SST dataset consists of monthly mean SSTs at a spatial resolution of a $5^{\circ}$ latitude-longitude regular-rectangular mesh, compiled at the UK Meteorological Office. The data over the latitudes extending from $55^{\circ} \mathrm{N}$ to $30^{\circ} \mathrm{S}$ during the years $1946-$ 1988 are analyzed in this study, since the spatial distribution of the SST observations is dense enough to perform a rotated empirical orthogonal function (REOF) analysis. This analysis deals with the global domain because the Asian summer monsoon may be coupled not only with SSTs over the Indian Ocean but also with the Pacific SSTs through the tropical east-west (Walker) circulation. The results of the R-EOF analysis used in the present analysis are performed by Kawamura (1994), which gives a further explanation and discusses robustness of the REOFs.

\section{Relationship between monsoon rainfall and global SSTs}

\subsection{Monsoon rainfall}

Over the Asian domain analyzed in this study, summer monsoon rainfall is defined as that summed from June to September, because the arrival and withdrawal of the summer monsoon over most of the domain occur within these four months.

Figure 1 shows June-September rainfall averaged over the period 1946-1988 (mm/month) (a) and the linear trends of the rainfall during this period (b). In Fig. 1b, the statistical significance of the linear trends is determined in accordance with Suzuki (1968). That is, the significance level for a given linear trend is determined by examining the possibility that we obtain, by chance, a linear trend whose real value is zero. The summer precipitation exceeds $200 \mathrm{~mm} /$ month over most of India and the western Indochina peninsula (Fig. 1a). In particular, rainfall is concentrated on the Indian west coast, the northeastern area of the Bay of Bengal, and the west coast of the Indochina peninsula. On the other hand, the map of the linear trends (Fig. 1b) illustrates that monsoon rainfall increases over southwest India and the northern part of India and Pakistan, while it decreases over central India, the western Indochina peninsula, and the southeastern side of the Himalayas.

All-India rainfall for the period 1850-1990 (Fig. 2 ) is calculated by averaging June-September rainfall for 50 stations that are uniformly distributed over India. The interannual variability is dominant throughout the period, while no distinct long-term trend is found in the five-year running mean (broken curve) and in the linear trend for the period 1946-1988 (broken line), respectively. 
(a)

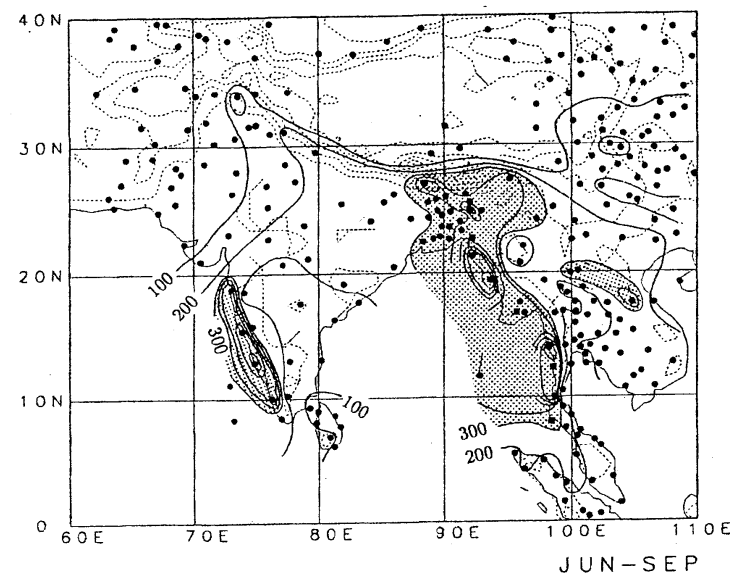

(b)

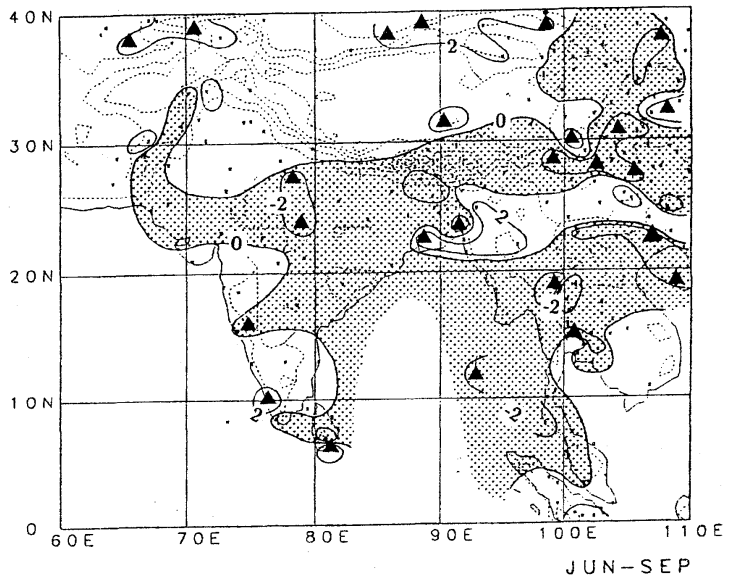

Fig. 1. Asian summer monsoon rainfall averaged over the period 1946-88 (a) and the linear trends for the same period (b). The contour intervals in Fig. $1 \mathrm{a}$ and $\mathrm{b}$ are $100 \mathrm{~mm} / \mathrm{month}$ and $2 \times 10^{-2} \mathrm{SD} / \mathrm{yr}$ , respectively. The stippling denotes areas exceeding rainfall of $300 \mathrm{~mm} /$ month (Fig. 1a) and areas having a decreasing trend (Fig. 1b). The closed circles in Fig. 1a reveal rain-gauge stations, while the closed triangle in Fig. 1b indicates a station which shows a linear trend significant at the $5 \%$ level. The broken line represents altitude and has an interval of $1000 \mathrm{~m}$.

RAINFALL TIME SER|ES, ALL INDIA

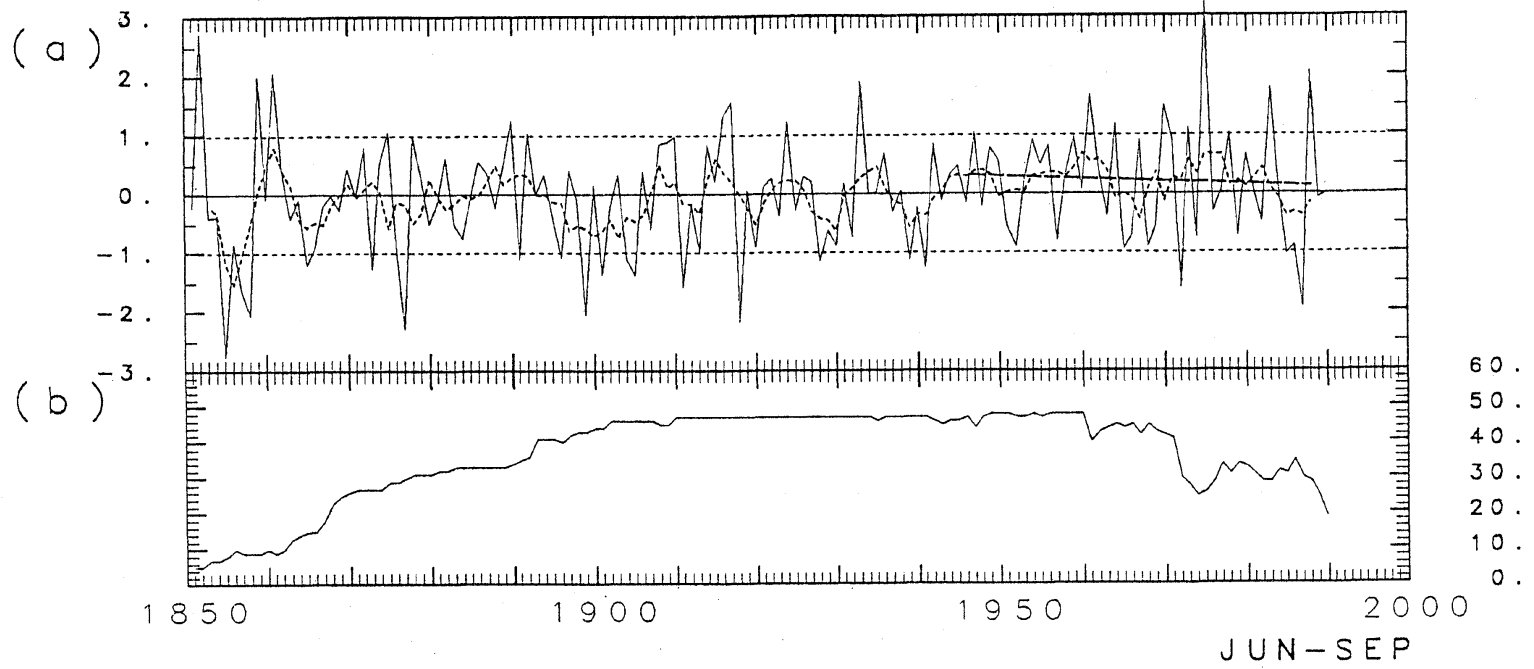

Fig. 2. All-India monsoon rainfall (a) and number of stations used for calculating the time series (b). Normalized rainfall for each station is averaged over India. The broken curve denotes the five-year running mean, while the broken line indicates the linear trend for 1946-88.

\subsection{Global SSTs}

As mentioned above, the results of the R-EOF analysis for global SST anomalies (Shinoda and Kawamura, 1994) is used in this study. The loading patterns and time coefficients of the first and second R-EOF mode (hereafter referred to as REOF1 and R-EOF2, respectively) are shown in Figs. 3 and 4, respectively. The R-EOF1 mode (Fig. 3), which explains $7.7 \%$ of the total variance, represents the ENSO phenomenon. In the loading pattern, large positive anomalies are found over the tropical central-eastern Pacific Ocean and dominant maxima in the time coefficients coincide with the occurrences of the El Niño events.

The R-EOF2 mode (Fig. 4), which explains $4.3 \%$ of the total variance, has two large signals in the loading pattern: negative anomalies over the north Pacific Ocean and positive anomalies over the Indian Ocean. The time coefficients indicate a significant increasing trend since the late 1950's.

\subsection{Correlation between monsoon rainfall and SST}

The correlation analysis between monsoon rainfall and SST R-EOF modes for June to September are performed in this subsection. 


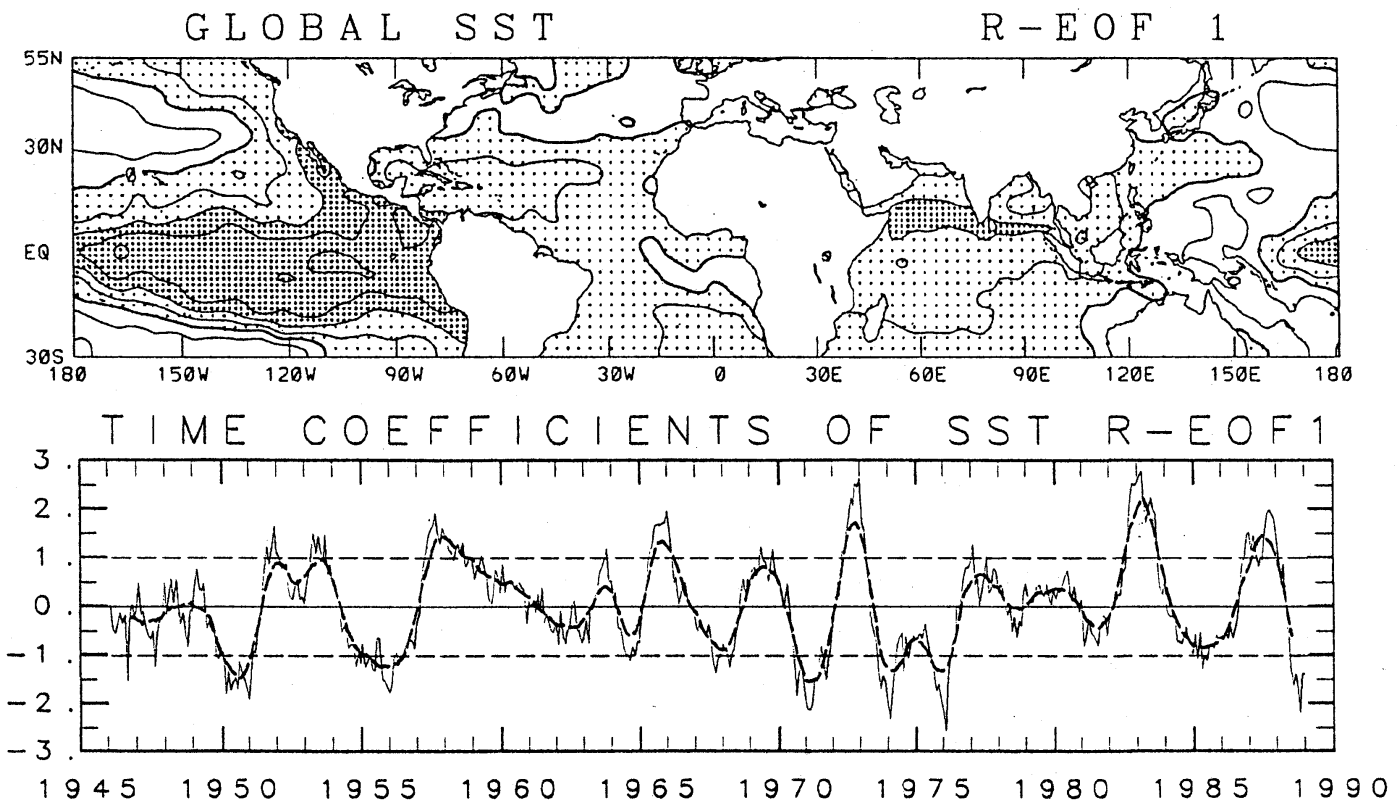

Fig. 3. Loading pattern (upper) and time coefficients (lower) of the R-EOF1 mode of global monthly SST anomalies for 1946-1988. The contour interval is 2.0 in relative units. The dark (light) stippling indicates values of more than $+4.0(+4.0$ to 0$)$, while the hatching denotes values of less than -4.0 . The broken line in the time coefficients reveals the 13 -month running mean.

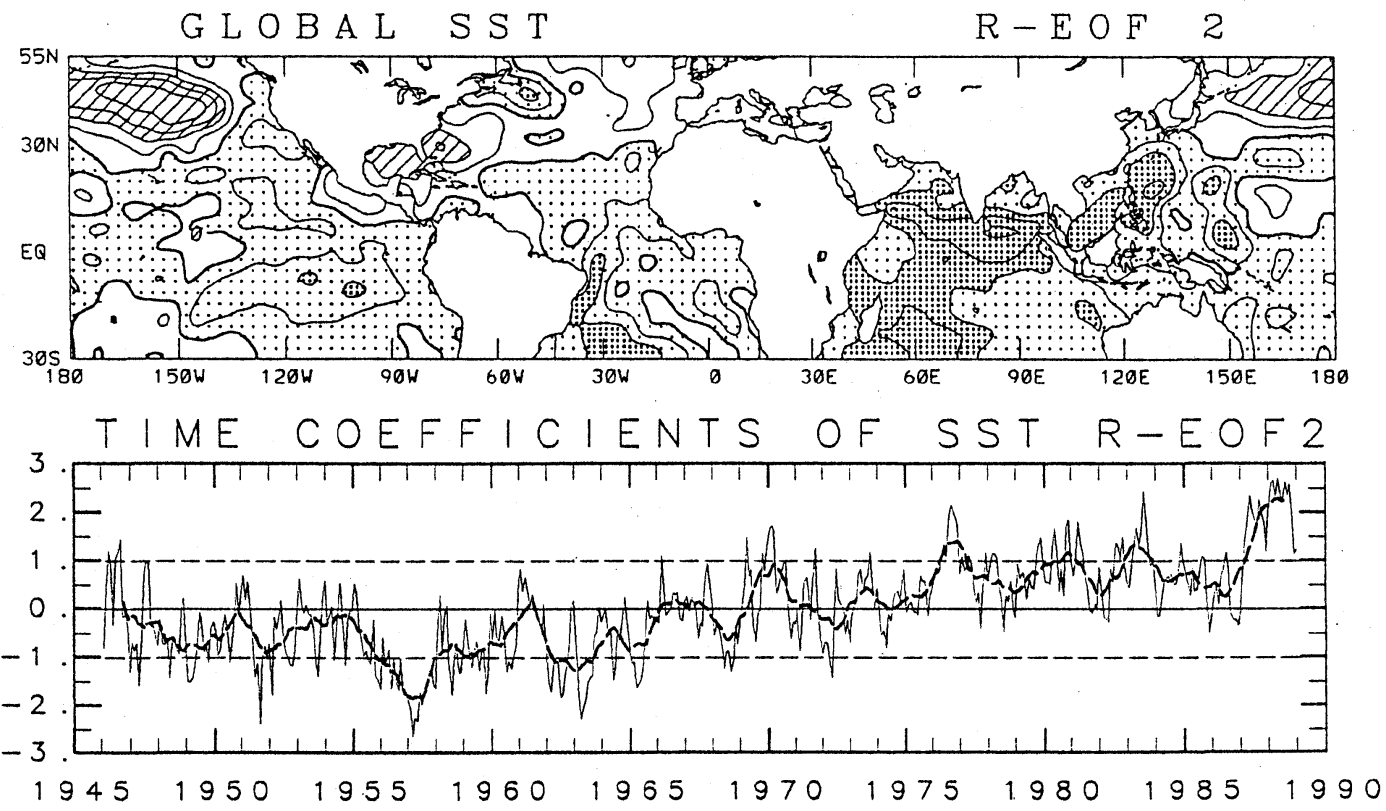

Fig. 4. As in Fig. 3, except for the R-EOF2 mode.

In order to separate the interannual and longterm variations, the original time series of JuneSeptember rainfall $\left(O_{r}\right)$ is divided into two components: long-term $\left(L_{r}\right)$ and year-to-year $\left(E_{r}\right)$ variation. Thus

$$
O_{r}=L_{r}+E_{r}
$$

where $L_{r}$ denotes the five-year running mean, while $E_{r}$ indicates the residual between $O_{r}$ and $L_{r}$. Over most of the Asian domain analyzed here, the variances of $E_{r}$ are three to four times as large as those of $L_{r}$ (not illustrated). The same procedure is applied to the time coefficients averaged over the summer season (June-September) for each R-EOF mode:

$$
O_{s}=L_{s}+E_{s} .
$$

Figure 5 shows the pattern of correlations between the interannual components of summer rainfall $\left(E_{r}\right)$ and the R-EOF1 mode $\left(E_{s}\right)$. Both time series $\left(E_{r}\right.$ and $E_{s}$ ) exhibit a wide-spread negative correlation over the study area. In Fig. 5, the absolute values 


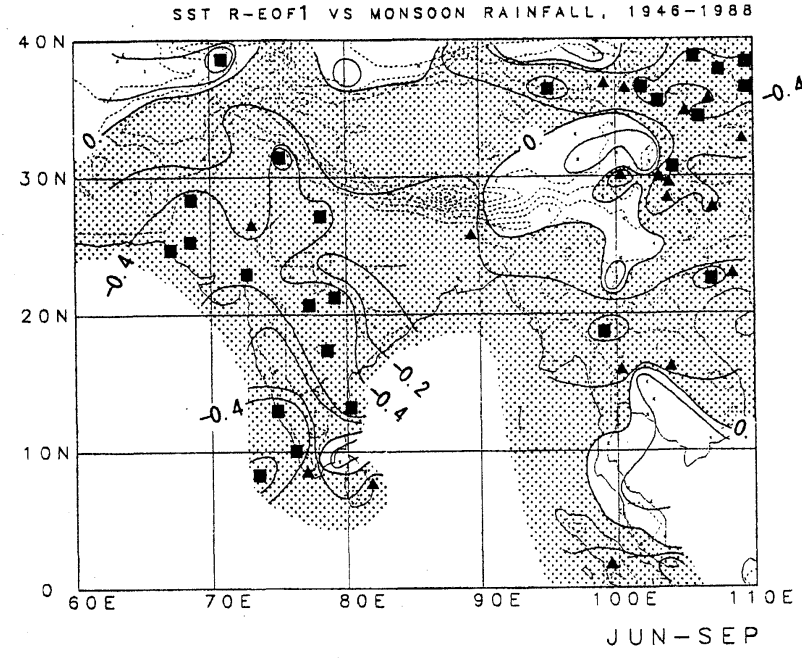

Fig. 5. Correlation between the interannual components of the summer rainfall $\left(E_{r}\right)$ and R-EOF1 mode $\left(E_{s}\right)$. The contour interval is 0.2 and areas having negative correlations are shaded. The closed square (triangle) indicates a station which shows the correlation coefficient significant at the $1 \%(5 \%)$ level.

of the correlation coefficient at $1 \%$ and $5 \%$ significance levels are 0.40 and 0.31 , respectively. It is found that summer rainfall over southwest-central India is negatively correlated, at the $1 \%$ level, with the ENSO-related R-EOF1 mode. The uniform pattern of correlation over India shown in Fig. 5 results in the high correlation between all-India rainfall and the $\mathrm{R}-\mathrm{EOF} 1$ mode $(-0.55)$. These results coincide with previous studies on the relationship between summer monsoon rainfall and ENSO (Rasmusson and Carpenter, 1983; Yasunari, 1990; among others).

The correlation pattern between the long-term variations of summer rainfall $\left(L_{r}\right)$ and the R-EOF2 mode $\left(L_{s}\right)$ (Fig. 6) reveals a pattern different from that shown in Fig. 5. The significance levels of the correlation coefficient become higher $(0.71$ and 0.58 at $1 \%$ and $5 \%$, respectively) because an effective sample size (Madden, 1976) of $L_{r}$ becomes smaller than $E_{r}$ due to running mean. Positive correlations are found over southwest India, while negative correlations occur over northwest-central India and the western part of the Indochina peninsula. It should be noted that this pattern resembles the pattern of linear trends of the summer rainfall (Fig. 1b). Contrary to Fig. 6, the correlations between the interannual components of summer rainfall $\left(E_{r}\right)$ and the R-EOF2 mode $\left(E_{s}\right)$ are less than \pm 0.2 almost over the domain (not shown). Therefore, the high correlation presented in Fig. 6 is attributed to the trend components which are observed in both the R-EOF2 mode and rainfall. Hastenrath and Rosen (1983)

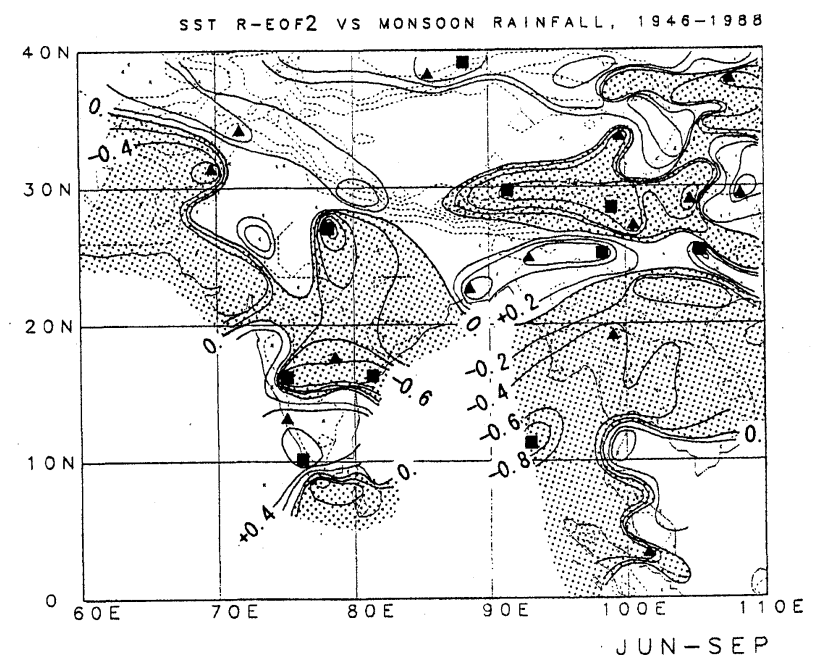

Fig. 6. As in Fig. 5, except for the correlation between the long-term variations of the summer rainfall $\left(L_{r}\right)$ and R-EOF2 mode $\left(L_{s}\right)$.

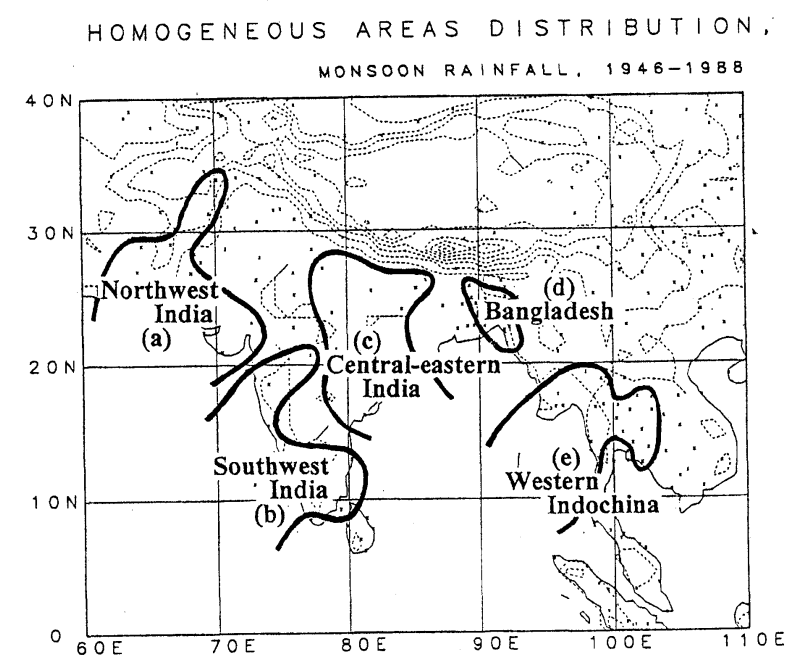

Fig. 7. Regional division according to the long-term variability of summer monsoon rainfall.

found similar overturning patterns of rainfall variability in central India and the west coast regions. They claimed that the pattern is related to the frequency of cyclonic storms in the Bay of Bengal and the Arabian Sea.

\section{Regional characteristics of the long-term variability}

Trend and correlation analyses suggest that the linear trend is dominant in the long-term variability of rainfall for recent decades. Then, several stations which exhibit a similar long-term variation are subjectively grouped into one region, as shown in Fig. 7, according to Figs. $1 \mathrm{~b}$ and 6 .

The rainfall time series for areas (a)-(e) (Fig. 8) 
(a) Northwest India
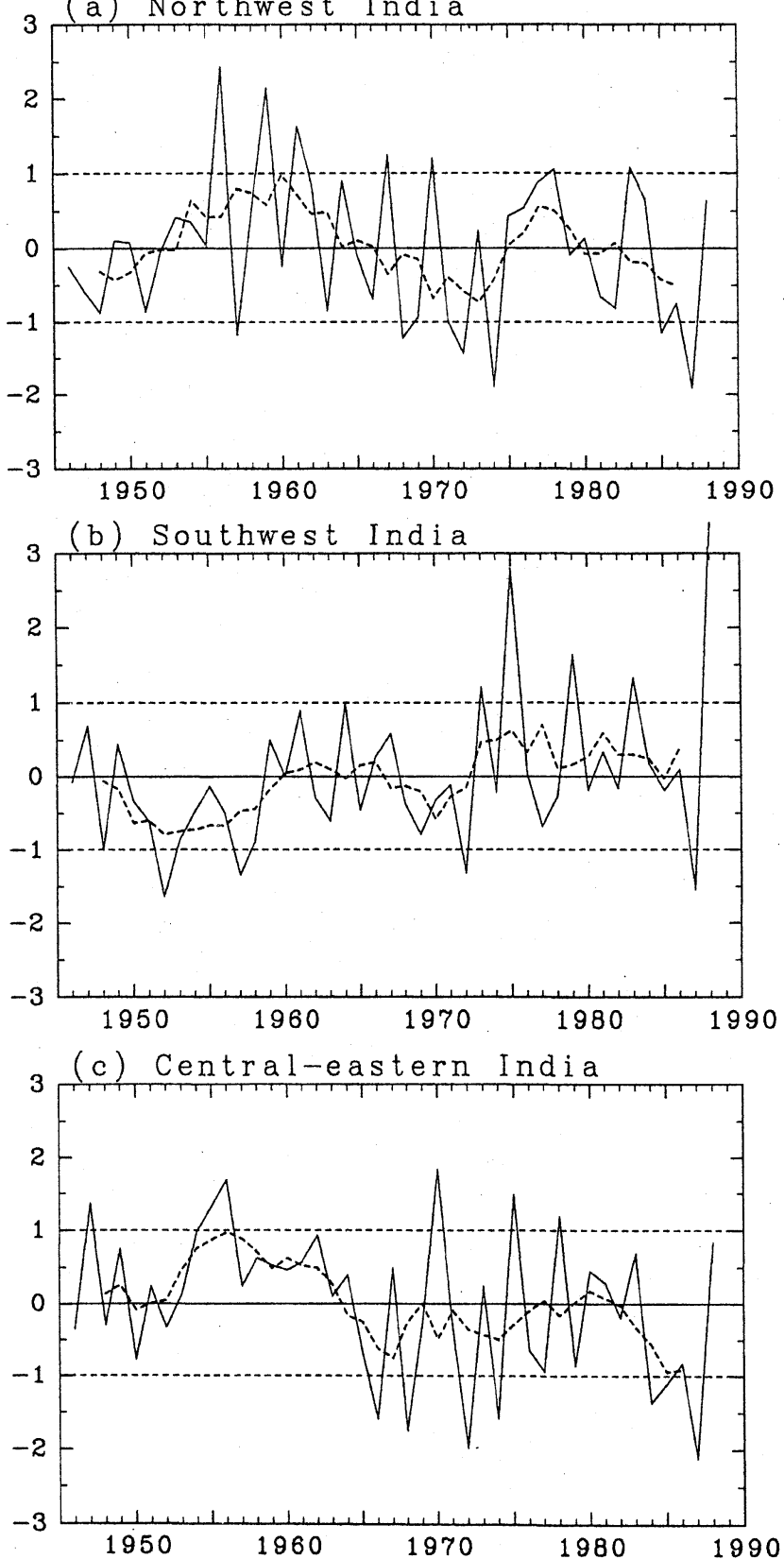
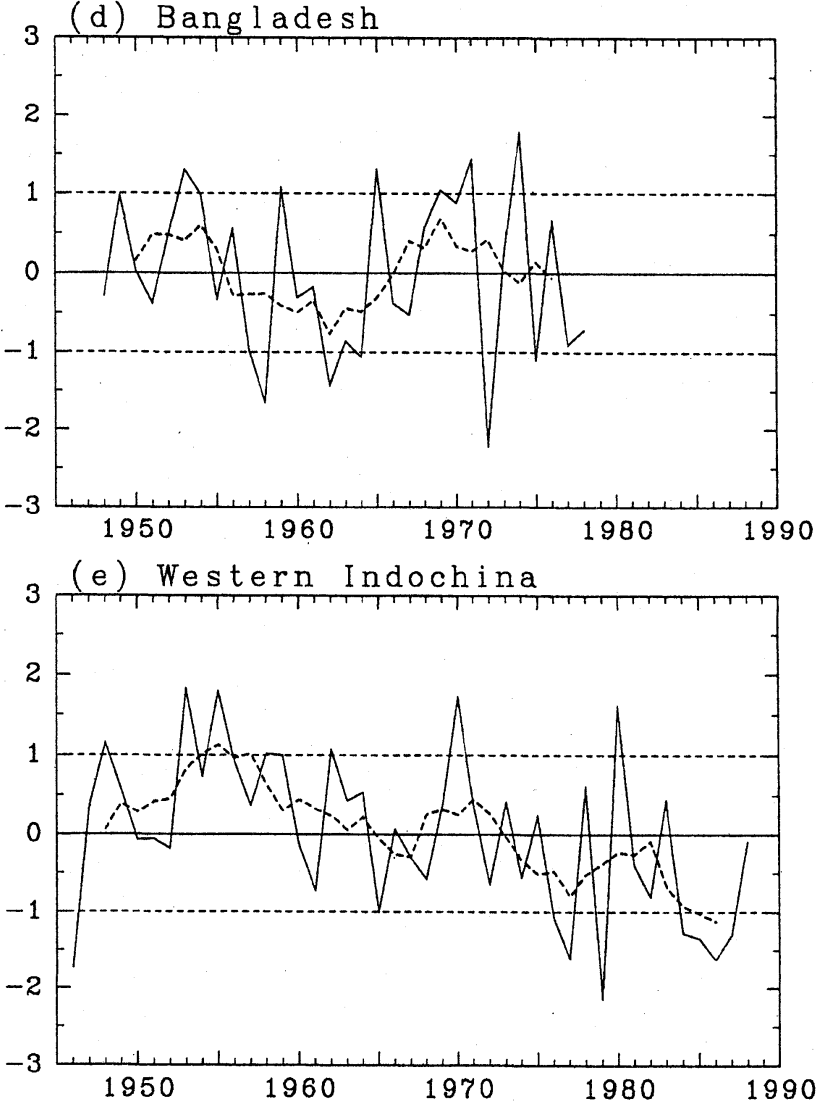

Fig. 8. Normalized June-September rainfall anomalies for the regions shown in Fig. 7. The broken lines denote the five-year running mean.

are produced by averaging the normalized rainfall anomalies for stations included in each region $(8,8$, $9,9,12$ stations for the areas (a)-(e), respectively).

It is found that rainfall is increasing in southwest India (b), while it is decreasing in northwest India (a), central-eastern India (c), and western Indochina (e) after the late 1950s. No significant long-term trend is observed in Bangladesh (d). The long-term component of R-EOF2 is correlated with those of rainfall over the area (b) and (c) at $5 \%$ and the area (e) at $1 . \%$ significant levels, respectively (Table 1). It should be noted that the long-term trend is not manifested when averaging the rainfall data over entire India. This results from an offset of different signs of trends that are observed in each regional rainfall.

The above-mentioned regional characteristics of the long-term variability of Asian summer monsoon rainfall are confirmed by a composite analysis. Figure 9 shows two composites of rainfall anomalies for two periods of continuous 11 years; 1950-60 (Fig. 9a) and 1975-85 (Fig. 9b). The two composites show a pattern having opposite signs of anomalies, being particularly pronounced over southwest India, central-eastern India and the western Indochina peninsula. 
Table 1. Correlation coefficients between the long-term component of the R-EOF2 mode and those of rainfall over five areas shown in Fig. 8. The single and double asterisks denote the $5 \%$ and $1 \%$ significance levels, respectively.

\begin{tabular}{cccccc}
\hline \multicolumn{5}{c}{ Regional rainfall } \\
\hline & $\mathrm{a}$ & $\mathrm{b}$ & $\mathrm{c}$ & $\mathrm{d}$ & $\mathrm{e}$ \\
\hline R-EOF2 & -0.523 & $0.680^{*}$ & $-0.706^{*}$ & 0.318 & $-0.822^{* *}$ \\
\hline
\end{tabular}

\section{Long-term trends in $850 \mathrm{hPa}$ heights}

Figure 10a illustrates the correlation between tropical $850 \mathrm{hPa}$ heights and the time coefficients of the R-EOF2 mode for June-September. This map exhibits an east-west contrast having positive correlations over Africa and the western Pacific Ocean, and negative correlations over western South America and the Indian west coast. A similar pattern is found in the linear trends of $850 \mathrm{hPa}$ heights (Fig. $10 \mathrm{~b})$. This suggests that the high correlations between tropical $850 \mathrm{hPa}$ heights and the time coefficients of the R-EOF2 mode over several tropical regions would be accounted for by the trend components in both time series. For instance, over Africa, the positive correlations of $850 \mathrm{hPa}$ heights with the R-EOF2 mode, which reveals a marked trend, are closely related to the increasing trends in the $850 \mathrm{hPa}$ heights. These trends may result in the decline of Sahelian rainfall (Shinoda and Kawamura, 1994). Similar increasing trends in $850 \mathrm{hPa}$ heights are found over the western equatorial Pacific, coinciding with a decreasing trend of SOI since the mid-1970s (Nitta and Yamada, 1989).

It should be noted that the negative trends in $850 \mathrm{hPa}$ heights over the Indian west coast (Fig. 10b) correspond to the increasing trends in rainfall over southwest India (Fig. 6). This results in the high correlation between summer rainfall and $850 \mathrm{hPa}$ heights over the area (Fig. 10c). These results suggest that the warming trends of the Indian Ocean, identified as the R-EOF2 mode, may be linked to the decreasing trends of $850 \mathrm{hPa}$ heights and the corresponding increasing trends of rainfall over southwest India.

\section{Monthly trends}

On a monthly basis, summer rainfall and associated geopotential heights reveal different long-term variations. The linear trends of monthly $850 \mathrm{hPa}$ heights for June to September are shown in Fig. 11. Similar increasing trends in $850 \mathrm{hPa}$ heights are found over Africa and the western Pacific Ocean throughout June--September. However, the patterns differ from month to month over the Indian subcontinent: negative trends over most of the India-

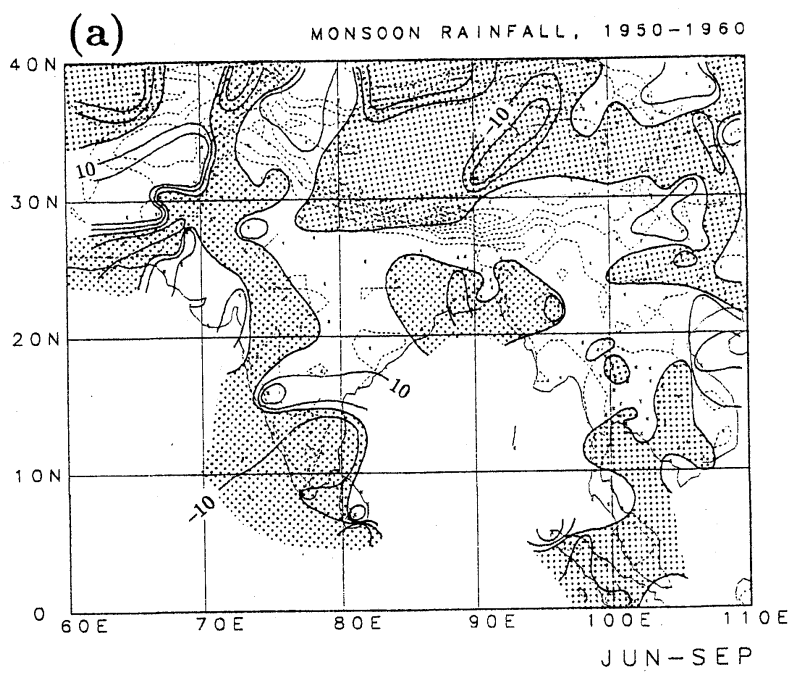

(b) MONSOON RAINFALL, 1975-1985

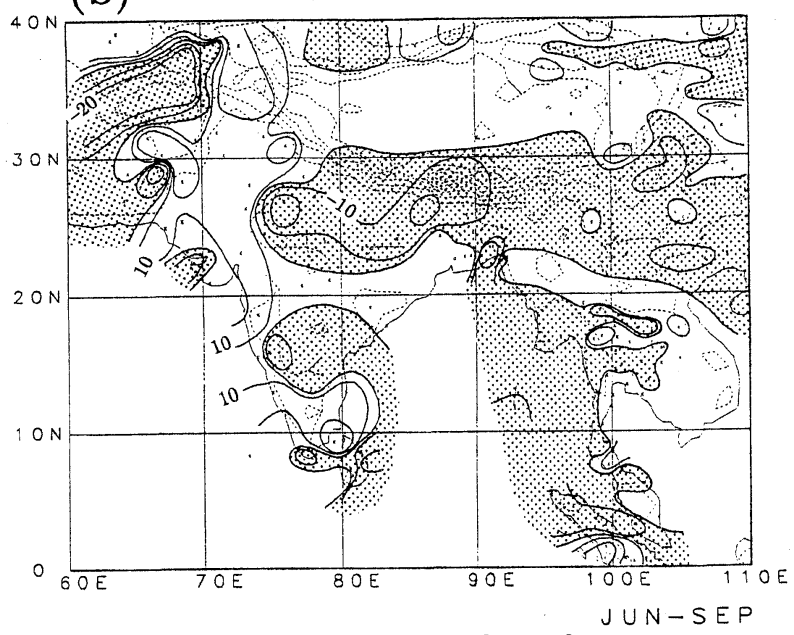

Fig. 9. Composite anomalies of summer monsoon rainfall for the period 1950-60 (a) and $1975-85$ (b). The units are the percentage deviation from the average for 1946-88. The contour interval is $10 \%$ and the stippling denotes areas having negative anomalies.

Indochina regions during June and August and positive trends over the western Pacific to central India during July and September.

Figure 12 shows a map of the correlation between the five-year running means of monthly rainfall $\left(L_{r}\right)$ and the R-EOF2 mode $\left(L_{s}\right)$ for June-September. For June and August, positive correlations are predominantly observed over India, while negative correlations occur over western Indochina. On the other hand, during July and September, negative correlations cover the India-Indochina peninsula regions except southwest India.

The trends of rainfall and associated trends of $850 \mathrm{hPa}$ heights over the India-Indochina region are schematically shown in Table 2. The rainfall over southwest India increases not only for JuneSeptember but also for each month, corresponding 
Table 2. Schematic representation for trends of rainfall and $850 \mathrm{hPa}$ height. Double signs in the trends of $850 \mathrm{hPa}$ height indicate the $5 \%$ statistical significance level.

\begin{tabular}{cccccc}
\hline & Rainfall & & \multicolumn{3}{c}{$850 \mathrm{hPa}$ height } \\
\hline & $\begin{array}{c}\text { Southwest } \\
\text { India }\end{array}$ & $\begin{array}{c}\text { central- } \\
\text { eastern India }\end{array}$ & $\begin{array}{c}\text { western } \\
\text { Indochina }\end{array}$ & $\begin{array}{c}\text { Indian } \\
\text { west coast }\end{array}$ & $\begin{array}{c}\text { central India- } \\
\text { Indochina }\end{array}$ \\
\hline Jun-Sep & + & - & - & - & + \\
Jun & + & + & - & -- & - \\
Jul & + & - & - & - & ++ \\
Aug & + & + & - & - & + \\
Sep & + & - & - & + & ++ \\
\hline
\end{tabular}

(a)

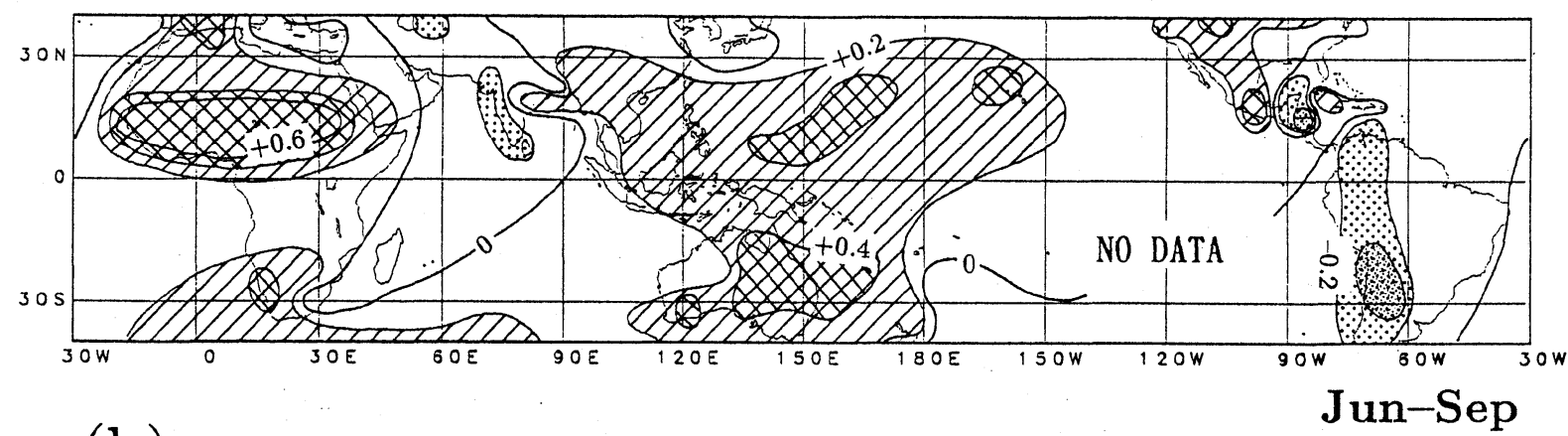

(b)

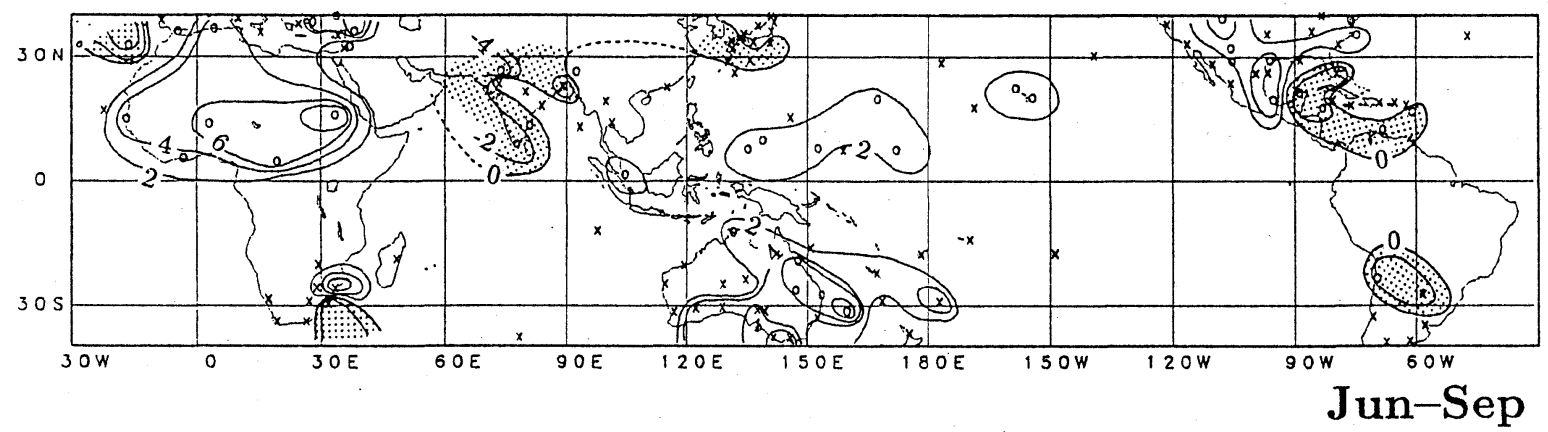

(c)

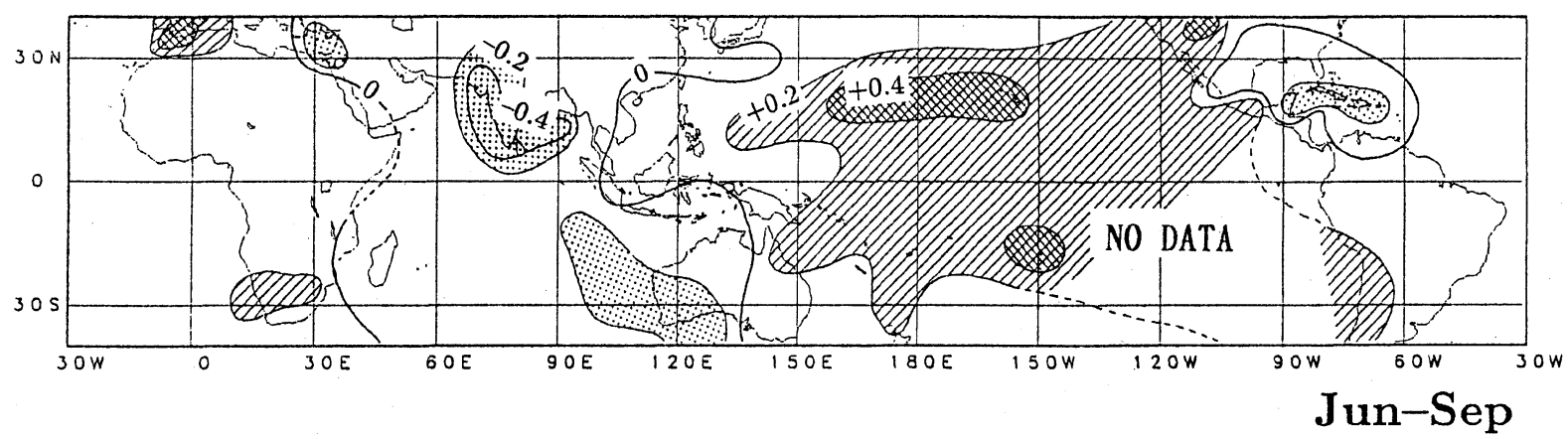

Fig. 10. Correlation between tropical $850 \mathrm{hPa}$ heights and the time coefficients of the R-EOF2 mode (a), linear trends of $850 \mathrm{hPa}$ heights for 1957-87 (b) and the correlation between the $850 \mathrm{hPa}$ heights and summer rainfall over southwest India (c). In Fig. 10a and c, the contour interval is 0.2 , the hatching (cross-hatching) indicates areas having a correlation coefficient of +0.2 to +0.4 (more than +0.4 ) while the light (dark) stippling denotes areas having a correlation coefficient of -0.2 to -0.4 (less than -0.4). The absolute values of correlation coefficients at the $5 \%$ and $1 \%$ significance levels are 0.39 and 0.50 , respectively. In Fig. $10 \mathrm{~b}$, the units are gpm per year and the contour interval is $2.0 \mathrm{gpm} / \mathrm{yr}$. The open circle (cross) denotes an observing station which shows the linear trend significant (non-significant) at the $5 \%$ level. Areas having a decreasing trend are stippled. 
(a)

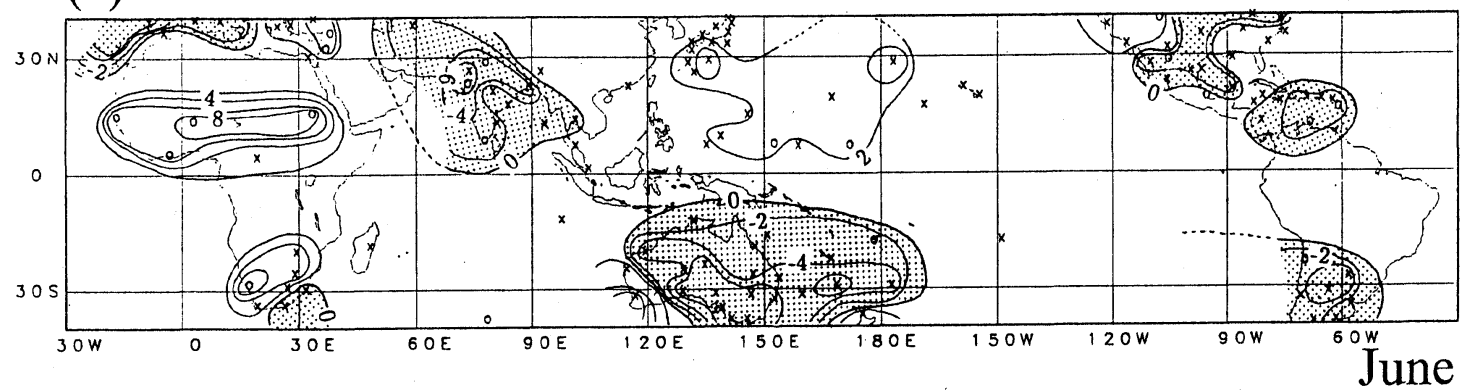

(b)

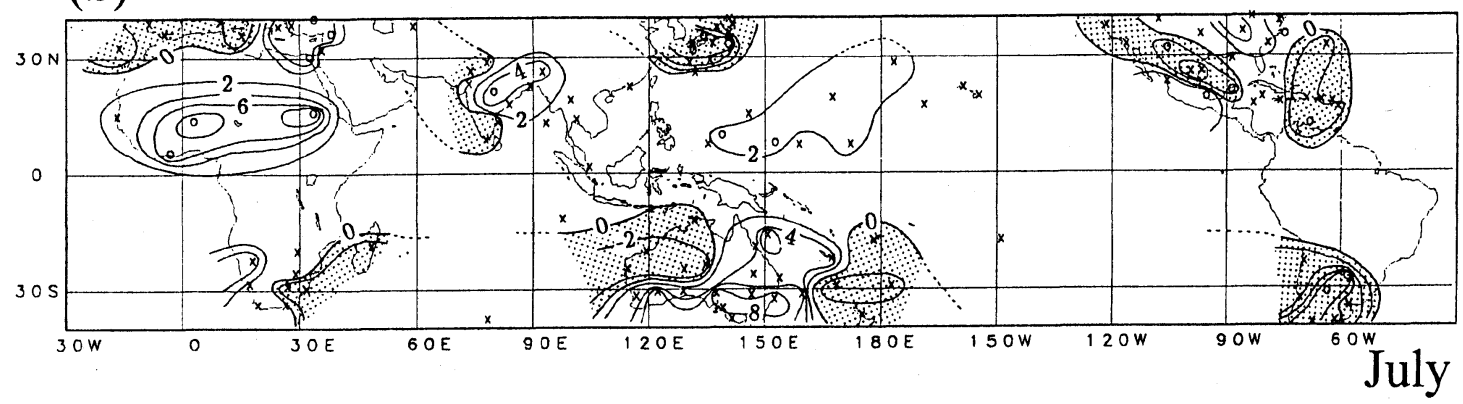

(c)

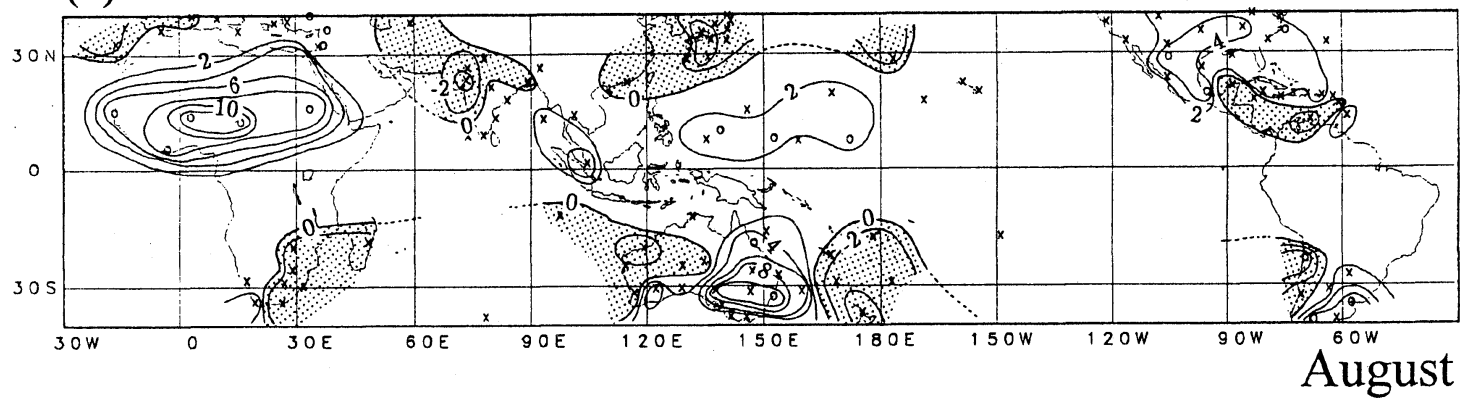

(d)

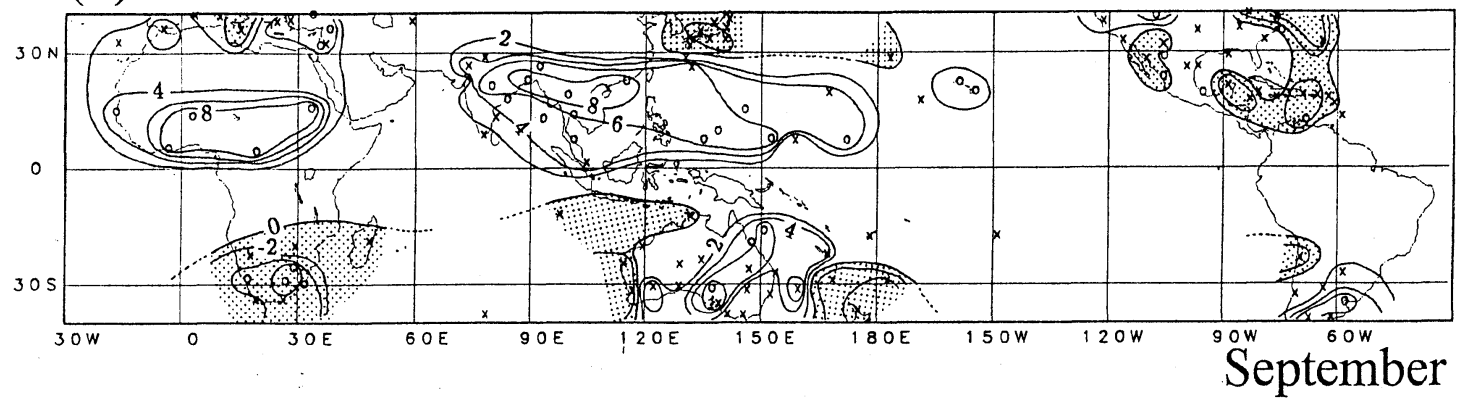

Fig. 11. As in Fig. 10b, except for the monthly (June to September) linear trends.

to the decreasing trends of $850 \mathrm{hPa}$ heights over the Indian west coast. Similarly, the decreasing trends of rainfall over the western Indochina peninsula coincide with the increasing trends of $850 \mathrm{hPa}$ heights over the central India-Indochina region during the summer monsoon season. On the other hand, the trends of rainfall over central-eastern India change their sign month to month: increasing trends dur- ing June and August when the decreasing trends of $850 \mathrm{hPa}$ heights are manifested over the Indian west coast, and decreasing trends during July and September when the increasing trends of $850 \mathrm{hPa}$ heights are predominant over the region between central India and the Indochina peninsula.

Although several local areas are not consistent with the relationship between rainfall and $850 \mathrm{hPa}$ 
(a)

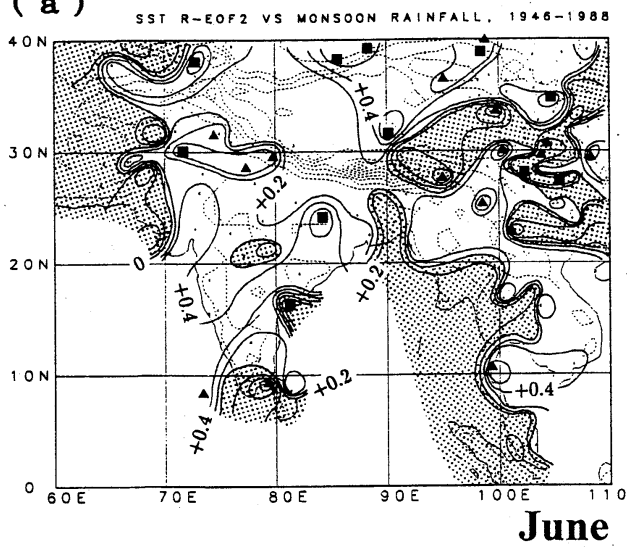

(c)

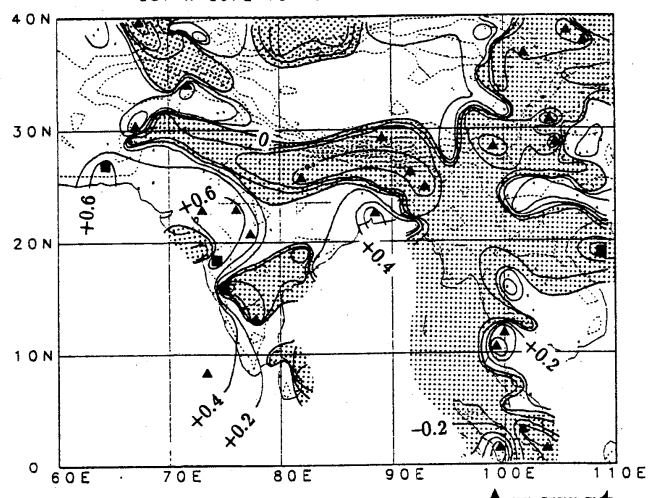

(b)

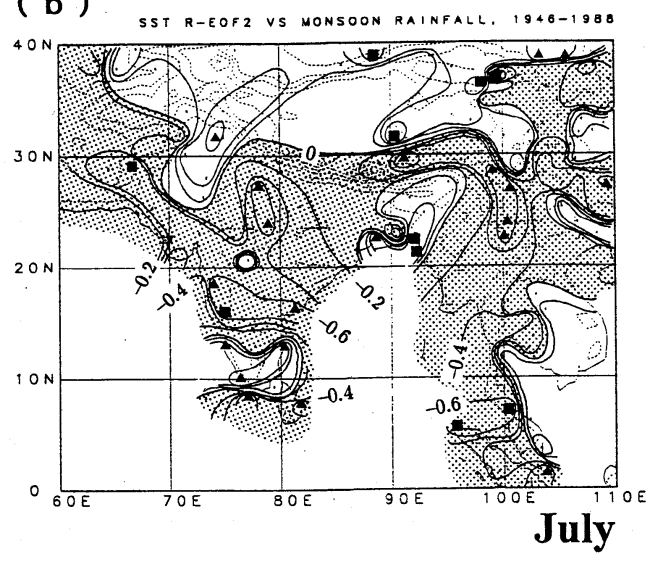

(d)

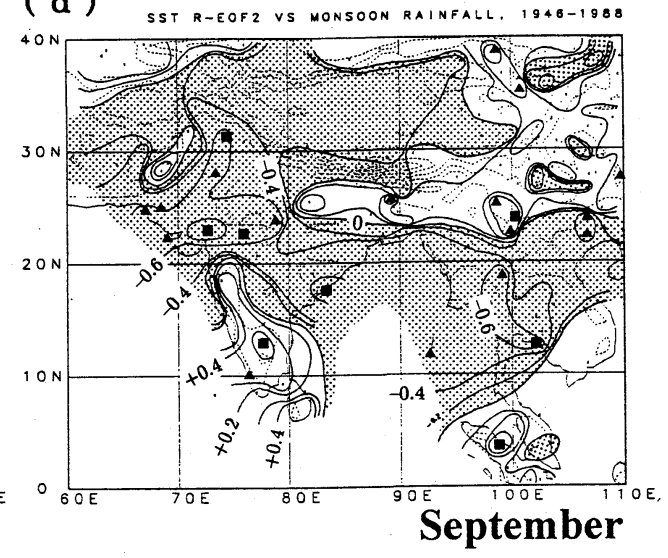

Fig. 12. As in Fig. 5, except fot he correlations between the long-term variations of the rainfall and R-EOF2 mode for (a) June, (b) July, (c) August, and (d) September.

heights on the seasonal and monthly time scales shown in Table 2, these discrepancies may be attributed to two reasons: sparse network of rawinsonde stations relative to the network of rain-gauge stations and/or some small-scale effects on the rainfall pattern such as orography.

\section{Summary and discussion}

The present study has shown the regional difference of the long-term variability of Asian summer monsoon rainfall during 1946-1988 and its relation to global SST anomalies and geopotential fields. The summer monsoon rainfall indicates a distinct long-term variability over several Asian regionsincreasing trends in southwest India and decreasing trends in northwest India, central-eastern India, and the western Indochina peninsula. This regional difference causes no significant long-term trend in all-India rainfall. The correlation analysis between R-EOF modes of global SSTs and Asian summer rainfall shows that the interannual component of the summer rainfall is closely related to the ENSO-related R-EOF1 mode, while the longterm variation is associated with the R-EOF2 mode which represents the warming of the Indian Ocean.
Also the regional difference of the long-term variability of rainfall is associated with the tropical eastwest contrasting pattern of tropical $850 \mathrm{hPa}$ heights having increasing trends over Africa and the western Pacific-Indochina region and decreasing trends over the Indian subcontinent, especially on the Indian west coast. This pattern may be related to the warming trend of the Indian Ocean.

The GCM study (Kitoh, 1992) has shown that the westerly moisture flux over the Arabian Sea shifts further southward when SSTs are above normal over the tropical Indian Ocean. This leads to increased rainfall over the southern tip of India and southward and decreased rainfall over the region extending from central India to the Indochina peninsula. These results seem to correspond to our results, although Kitoh's study focused on the interannual variability, not the long-term trend. Thus, the simultaneous occurrence of increased rainfall over southwest India and decreased rainfall over centraleastern India and western Indochina (Fig. 8) may result from the southward shift of the moisture flux linked to the warming trend of the Indian Ocean.

The recent warming of the Indian Ocean, as manifested as the R-EOF2 mode, may result in enhance- 
ment of the convective activity over the Indian west coast and its weakening over tropical Africa and the western Pacific region (Fig. 10a and b). This circulation pattern indicates the weakening of the tropical east-west circulation. The R-EOF2 mode displays the secondary positive signals over the eastern $\mathrm{Pa}$ cific (Fig. 4), as has also been pointed out by Nitta and Yamada (1989). These signals may be physically coupled with the negative anomaly over the north Pacific Ocean shown in the R-EOF2 mode (Trenberth and Hurrell, 1994; Graham, 1994).

Figures 11 and 12 show the monthly characteristic of the long-term trends for both summer rainfall and $850 \mathrm{hPa}$ heights over the central IndiaIndochina regions-dominances of the increasing trends of rainfall and decreasing trends of $850 \mathrm{hPa}$ heights during June and August and those of nearly opposite signs during July and September. This monthly difference is a remarkable feature of the long-term variability of the Asian summer monsoon. This implies that the long-term variability of the monthly rainfall is related to the active/break cycle of the summer monsoon having a periodicity of 30-40 days.

It is difficult to explain the long-term variability of the Asian summer monsoon simply by the warming effect of the Indian Ocean. The decreasing trends of the Eurasian snow cover during the past 20 years have been pointed out by Robinson et al. (1993) and Groisman et al. (1994). It should be further investigated how the Eurasian snow cover, which is strongly correlated with Indian summer monsoon rainfall on an interannual basis (Hahn and Shukla, 1976), affects the long-term variability of the Asian summer monsoon.

\section{Acknowledgments}

The authors are grateful to Dr. R. Kawamura, National Research Institute for Earth Science and Disaster Prevention, for giving the results of the R-EOF analysis of global SSTs. We are indebted to Dr. R.S. Vose and the principal investigators of CDIAC for providing the monthly precipitation dataset. Thanks are also due to Dr. H. Matsuyama, Department of Geography, Tokyo Metropolitan University, and Dr. J. Matsumoto, Department of Geography, the University of Tokyo, for their helpful comments.

\section{References}

Alvi, S.M.A. and P. Koteswaram, 1985: Time series analysis of annual rainfall over India. Mausam, 36, 479-490.

Cadet, D.L. and B.C. Diehl, 1984: Inaterannual variability of surface fields over the Indian Ocean during recent decades. Mon. Wea. Rev., 112, 1921-1935.
Fu, C. and J. Fletcher, 1988: Large signals of climatic variations over the ocean in the Asian monsoon region. Adv. Atmos. Sci., 5, 389-404.

Ghosh, S.K., M.C. Pant and B.N. Dewan, 1978: Influence of the Arabian Sea on the Indian summer monsoon. Telluis, 30, 117-125.

Graham, N.E., 1994: Decadal-scale climate variability in the tropical and North Pacific during the 1970s and 1980s: observations and model results. Clim. Dyn., 10, 135-162.

Groisman, P.Y., T.R. Karl, R.W. Knight and G.L. Stenchikov, 1994: Changes of snow cover, temperature, and radiative heat balance over the Northern Hemisphere. J. Climate, 7, 1633-1656.

Hahn, D.G. and J. Shukla, 1976: An apparent relationship between Eurasian snow cover and Indian monsoon rainfall. J. Atmos. Sci, 33, 2461-2462.

Hastenrath, S. and A. Rosen, 1983: Patterns of India monsoon rainfall anomalies. Tellus, 35A, 324-331.

IPCC, 1996: Climate change. The IPCC Sientific Assessment, eds. J.T. Houghton, L.G.M. Filho, (in press).

Jagannathan, P. and B. Parthasarathy, 1973: Trends and periodicities of rainfall over India. Mon. Wea. Rev., 101, 371-375.

Kawamura, R., 1994: A rotated EOF analysis of global sea-surface temperature variability with interannual and interdecadal scales. J. Phys. Oceanogr., 24, 707715.

Kitoh, A., 1992: Simulated interannual variations of Indo-Australian monsoons. J. Meteor. Soc. Japan, 70, 563-583.

Kripalani, P.H. and S.V. Singh, 1993: Large scale aspects of India-China summer monsoon rainfall. $A d v$. Atmos. Sci., 10, 71-84.

Kumar, M.R., G.B. Pant, B. Parthasarathy and N.A. Sontakke, 1992: Spatial and subseasonal patterns of the long-term trends of Indian summer monsoon rainfall. J. Climatol., 12, 257-268.

Madden, R.A., 1976: Estimates of the natural variability of time-averaged climate means. Mon. Wea. Rev., 104, 942-952.

Mooley, D.A. and B. Parthasarathy, 1984: Fluctuations in all-India summer monsoon rainfall during 18711978. Clim. Change, 6, 287-301.

Murakami, T. and J. Matsumoto, 1994: Summer monsoon over the Asian continent and western north Pacific. J. Meteor. Soc. Japan, 72, 191-210.

Nitta, T. and S. Yamada, 1989: Recent warming of tropical sea surface temperature and its relationship to the northern hemisphere circulation. J. Meteor. Soc. Japan, 67, 375-383.

Parker, D.E. and D.I. Cox, 1995: Towards a consistent global climatological rawinsonde data-base. Int. J. Climatol., 15, 473-496.

Parthasarathy, B., K.R. Kumar and A.A. Munot, 1991: Evidence of secular variations in Indian monsoon rainfall-circulation relationships. J. Climate, 4, 927938.

Parthasarathy, B., A.A. Munot and D.R. Kothawale, 1994: All-India monthly and seasonal rainfall series: 1871-1993. Theor. Appl. Climatol., 49, 217-224. 
Raghavan, K., P.V. Puranik, V.R. Mujumdar, P.M.M. Ismail and D.K. Paul, 1978: Interaction between the west Arabian sea and the Indian monsoon. Mon. Wea. Rev., 106, 719-724.

Rao, K.G. and B.N. Goswami, 1988: Interannual variations of sea surface temperature over the Arabian Sea and the Indian monsoon. A new perspective. Mon. Wea. Rev., 116, 558-568.

Rasmusson, E.M. and T.H. Carpenter, 1983: The relationship between eastern equatorial Pacific sea surface temperatures and rainfall over India and Sri Lanka. Mon. Wea. Rev., 111, 558-568.

Robinson, D.A., K.F. Dewey and R.R. Heim, 1993: Global snow cover monitoring: An update. Bull. Amer. Meteor. Soc., 74, 1689-1696.

Ropelewski, C.F. and M.S. Halpert, 1987: Global and regional scale precipitation patterns associated with the El Niño/Snouthern Oscillation. Mon. Wea. Rev., 115, 1606-1626.

Shinoda, M., 1995: West African rainbelt variation: An update to 1990. J. Meteor. Soc. Japan, 73, 259-266.

Shinoda, M. and R. Kawamura, 1994: Tropical rain- belt, circulation and sea surface temperatures assosiated with the Sahelian rainfall trend. J. Meteor. Soc. Japan, 72, 341-357.

Shukla, J., 1987: Interannual variability of monsoons. Monsoons, eds. J.S. Fein and P.L. Stephens, 399-438, Wiley, New York.

Shukla, J. and B.M. Misra, 1977: Relationships between sea surface temperature and wind speed over ther Central Arabian Sea, and monsoon rainfall over India. Mon. Wea. Rev., 105, 998-1002.

Suzuki, E., 1968. Statistical Meteorology, Chijinshokan, Tokyo, 314p (in Japanese).

Trenberth, K.E. and J.W. Hurrell, 1994: Decadal atmosphere-ocean variations in the Pacific. Clim. Dyn., 9, 303-319.

Weare, B.C., 1979: A statistical study of the relationships between ocean surface temperatures and the Indian monsoon. J. Atmos. Sci., 36, 2279-2291.

Yasunari, T., 1990: Impact of Indian monsoon on the coupled atmosphere/ocean system in the tropical Pacific. Meteor. Atmos. Phys., 44, 29-41.

\section{6-1988 年の夏季アジアモンスーンの長期変動 \\ 渡部雅浩 1 篠田雅人 \\ (東京都立大学理学部地理学教室)}

1946-1988 年の夏季アジアモンスーン降水量の長期変動を解析し、全球の海水面温度(SST) および下部対 流圈の等圧面高度との関係を調べた。最近の数十年で、夏季アジアモンスーン降水量は地域により傾向の異 なる長期変動を示す。すなわち、6-9月の降水量はインド南西部で増加、北西拉よび中部インド、ヒマラヤ 南麓、そしてベンガル湾に面したインドシナ半島西部で減少している。上記の 43 年間の全球のSSTアノマ リに回転経験的直交関数 (R-EOF) 解析を行なうと (Shinoda and Kawamura, 1994)、第二成分(R-EOF2) はインド洋SSTの昇温傾向を示す。この R-EOF2 と夏季モンスーン降水量との相関解析の結果は、両者の 高い相関がそれぞれの線型傾向に依っていることを示している。SSTの R-EOF2 モードはモンスーン降水 量だけでなく、熱带の $850 \mathrm{hPa}$ 等圧面高度とも高い相関をもつ。また、高い相関を示す地域では、 $850 \mathrm{hPa}$ 高度が顕著な線型傾向を示している。線型傾向のパターンは、アフリカと西太平洋で高圧傾向、インド洋 北部で低圧傾向という東西対照性を示している。インド亜大陸上では、降水量の増加している地域、減少 している地域が下部対流圈の低圧傾向、高圧傾向にそれぞれ対応している。6-9月の各月の解析から、夏 季アジアモンスーンの長期変動は興味深い特徵を示すことが分かった。すなわち、6・8月には降水量増 加傾向と $850 \mathrm{hPa}$ 高度の低圧傾向がインド全域に広がる一方、7・9月にはそれらはインド南西部に限られる。

\footnotetext{
1現所属：東京大学気候システム研究センター
} 